\title{
Sympathy for the environment predicts green consumerism but not more important environmental behaviours related to domestic energy use
}

\author{
XIAODONG CHEN ${ }^{1 *}$, JENNIFER DE LA ROSA ${ }^{1}$, M. NILS PETERSON ${ }^{2}$, YING ZHONG ${ }^{3}$ AND \\ CHUNTIAN LU ${ }^{4}$ \\ ${ }^{1}$ Department of Geography, University of North Carolina at Chapel Hill, Saunders Hall, Campus Box 3220, Chapel Hill, NC 27599, USA, \\ ${ }^{2}$ Fisheries, Wildlife and Conservation Biology Program, Department of Forestry E Environmental Resources, North Carolina State University, Box \\ 7646, Raleigh, NC 27695, USA, ${ }^{3}$ School of Journalism and Communications, China West Normal University, Shi Da Road, Nanchong, Sichuan \\ 637002, China and ${ }^{4}$ College of Social Science, Xi'an Fiaotong University, Xian Ning West Road, Xi'an, Shaanxi 710049, China \\ Date submitted: 26 February 2015; Date accepted: 16 September 2015; First published online 13 January 2016
}

\section{SUMMARY}

Household consumption is a major contributor to global greenhouse gas emissions. Some behaviours (for example energy use and vehicle use) may have far larger impacts than others (for example green consumerism of household products). Here, the driving forces of green consumerism and two domestic energy uses (electricity consumption and vehicle fuel use) are compared. This study found that environmental attitudes predicted green consumerism, but not electricity consumption or vehicle fuel use. Furthermore, green consumerism was correlated with income and individual level demographic factors, while energy consumption was primarily predicted by household size and structural constraints. Because household energy consumption has greater environmental impacts than green consumerism, policies that aim to improve pro-environmental attitudes may not be effective in mitigating greenhouse gas emissions. Policies should rather aim to change structural constraints influencing transportation and household energy decisions and improve the conspicuousness of household energy consumption.

Keymords: energy consumption, environmental behaviour, environmental impacts, green consumerism, proenvironmental attitude

\section{INTRODUCTION}

Humans are increasingly emitting greenhouse gases, resulting in global climate change (IPCC 2014). The USA contributes to $21 \%$ of the world's greenhouse gas emissions, and household consumption accounts for more than $80 \%$ of these emissions (Jones \& Kammen 2011); c. 98\% of the emissions derive from energy consumption (Attari et al. 2010). Although direct household impacts (such as use of products and services in homes) make up about one-third of US energy consumption, much more energy is consumed through indirect household

*Correspondence: Dr Xiaodong Chen Tel: +1 9199628901 e-mail: chenxd@email.unc.edu impacts (such as energy consumption associated with the production and delivery of products and services) because energy use is embedded in the production, transportation and disposal of consumer goods and services (Bin \& Dowlatabadi 2005). Because housing uses the most energy, and is the least efficient sector in terms of energy use, it holds the key for reducing greenhouse gas emissions (Peterson et al. 2013). Households in the US can reduce energy consumption by approximately $30 \%$ without impacting general quality of life, which would cut approximately $11 \%$ of total US energy consumption (Gardner \& Stern 2008). Furthermore, most US residents would like to reduce their emissions by changing their behaviour, and many people believe that they are doing so (Gardner \& Stern 2008).

However, consumers and scholars often fail to differentiate environmental behaviours with drastically different environmental impacts. For example, a US household emits an average of 48 tonnes of $\mathrm{CO}_{2}$ per year, where transportation, home energy and food account for approximately 32,21 and $15 \%$ of the household $\mathrm{CO}_{2}$ emissions, respectively (Bin \& Dowlatabadi 2005; Jones \& Kammen 2011). Many previous studies have focused on environmental behaviours that have relatively low impacts on energy or material use (Gatersleben et al. 2002). These studies may provide little insight into environmental behaviours that have major impacts on the environment (Gatersleben $e t$ al. 2002); thus people who have been identified as behaving more pro-environmentally may not necessarily have less impact on the environment. This creates a need for research addressing how predictors of environmental behaviour vary across more and less significant behaviours.

Many studies on pro-environmental behaviours have used green consumerism - purchasing and consuming products that are marketed as benign or beneficial for the environment (Mainieri et al. 1997) - as a measure of behaving pro-environmentally. Examples include purchasing locally produced products or products that are made of recycled materials. Compared to the impacts of household energy use, the positive environmental contributions from green consumerism are quite low (Peterson et al. 2013), indeed green consumerism may scarcely reduce the environmental impact of consumption (Alfredsson 2004; Csutora 2012). The focus on green consumerism may have emerged from the 
relative simplicity of changing brands when shopping and the aggressive marketing of green products intended to capitalize on green premiums (Gatersleben et al. 2002). Engaging in green consumerism may also be considered a symbolic way to demonstrate environmental values to peers (Pedersen \& Neergaard 2006). Furthermore, once people are engaged in some pro-environmental behaviours, they may have less impetus to engage in others (Moisander 2007).

Studies on the drivers of environmental behaviour have found consistent, sometimes weak, correlations between pro-environmental attitudes and behaviours (Buttel 1987; Dunlap et al. 2000). Weak correlations between attitudes and behaviours were partially due to low correlations among different types of environmental behaviours (Mainieri et al. 1997). Females and more educated people were more likely to engage in pro-environmental behaviours (Stern et al. 1993; Scott \& Willits 1994; Vaske et al. 2001; Hunter et al. 2004). Findings on the relationship between income and environmental behaviour are mixed. Some studies find a positive relationship between income and pro-environmental behaviour, suggesting that people may often emphasize environmental quality after their material needs are well satisfied (Van Liere \& Dunlap 1980; Scott \& Willits 1994; Jones \& Kammen 2011). However, others have found similar pro-environmental attitudes among people of poor countries (Brechin \& Kempton 1994; Dunlap \& Mertig 1995; Brechin 1999; Dunlap \& York 2008), and even found that people who have experienced environmental harm may be more likely to engage in pro-environmental behaviour than their wealthier counterparts (Chen et al. 2013). Findings on the relationship between age and environmental behaviour are also mixed (Scott \& Willits 1994; Stern et al. 1995; Tindall et al. 2003).

Different types of environmental behaviours have different impacts on people's lives, and are often affected by different drivers; however, the drivers of different environmental behaviours are unclear. People with more pro-environmental attitudes were more likely to engage in green consumerism (Mainieri et al. 1997; Roberts \& Bacon 1997; Gatersleben et al. 2002). Females, older people and people with higher education were more likely to engage in green consumerism (Mainieri et al. 1997; Gatersleben et al. 2002). The relationship between pro-environmental attitudes and energy use is unclear. Proenvironmental attitudes affected people's energy use in some studies (Roberts \& Bacon 1997; Barr et al. 2005; Nelson et al. 2012), but not in others (Becker et al. 1981; Gatersleben et al. 2002; Abrahamse \& Steg 2009). Households with a higher income and more people tended to consume more energy (Gatersleben et al. 2002; Abrahamse \& Steg 2009), though high income households consumed less energy per unit of area (Nelson et al. 2012). In addition, people who choose to tolerate warmer inside temperatures in the summer or cooler inside temperatures in the winter used less energy (Becker et al. 1981; Nelson et al. 2012; Brounen et al. 2013).

Collectively these diverse findings indicate that marketing may hijack environmental attitudes so that intentionally green behaviour decisions are aimed at relatively insignificant green consumerism, and social and structural variables primarily drive more meaningful behaviours, including home and transportation energy usage. In this research, we explored the driving forces of three types of environmental behaviours, namely green consumerism, housing electricity consumption and vehicle fuel consumption. We evaluated the effects of attitudinal and demographic factors, and social and structural conditions on these environmental behaviours, and assessed correlations among different environmental behaviours.

\section{METHODS}

\section{Data collection}

Our case study was conducted in Chapel Hill (North Carolina, USA). The educational attainment of residents in this area is relatively high; $24 \%$ of residents have a Master's degree or above, compared to a nation-wide average of only $7 \%$ (Social Explorer 2010). Community regulations promoting recycling and energy conservation, and the prevalence of buy local and buy green stores suggest green consumerism is relatively salient and common in this area. We conducted mail-in surveys with 535 randomly selected households in 2013. We received 186 responses, and only one of them was not appropriately completed, resulting in 185 valid responses (35\% response rate). In order to identify potential for differences between respondents and non-respondents, we randomly selected 36 households from non-respondents and reached 34 households. We asked three questions to these 34 households, namely the age and ethnicity of respondents and the floor area of households. Independent sample $t$-tests (for age and floor area) and a chi-square test (for ethnicity) showed no significant differences $(p>0.05)$ between the respondents and non-respondents for these variables.

In our survey, green consumerism was measured using respondents' engagement in purchasing six green products that are commonly used in green consumerism studies: fairtrade coffee or tea, phosphate-free laundry detergent, recycled writing paper, recycled toilet paper, organic food and locally produced products (Sparks \& Shepherd 1992; Roberts 1996; Gilg et al. 2005). We measured how often the respondents purchased green products using a five-category rating scale, ranging from 'never' to 'always'. We asked respondents about their monthly electricity bills for June, July and August of 2012. Because respondents' electricity was supplied through Duke Energy Corporation, the same electricity prices applied to all respondents. Therefore, an aggregation of three summer month bills was used as an indicator of housing electricity consumption. In order to measure the vehicle fuel consumption, we asked the make, model, year and distance driven in the respondents' primary vehicle during the past year. We then used this data in combination with the fuel efficiency for each vehicle from fueleconomy.gov to calculate the annual fuel consumption for each vehicle. 
Respondents' environmental attitudes were measured with the New Ecological Paradigm (NEP) scale (Dunlap et al. 2000). The NEP measures an individual's environmental worldview in five aspects: the realization of limits to growth, anti-anthropocentrism, belief in the fragility of the balance of nature, rejection of human exemptionalism and belief in future eco-crisis. Respondents were asked about their perceptions of 15 statements by choosing a value for each statement from five-category Likert responses ranging from strongly disagree to strongly agree. Agreement with eight positively narrated statements corresponds to higher measures, while responses to the seven negatively narrated statements were reversed so that disagreement with these statements corresponds to higher measures. Past studies have found higher NEP scores among members of environmental organizations than that of the general public (Dunlap \& Van Liere 1978; Widegren 1998; Dunlap et al. 2000; Dunlap \& Michelson 2002). Studies have also found significant correlations between NEP score and pro-environmental behaviour and intentions (Vining \& Ebreo 1992; Scott \& Willits 1994; Stern et al. 1995; Schultz \& Oskamp 1996; Tarrant \& Cordell 1997; Schultz \& Zelezny 1998).

We measured seven sociodemographic variables that were often used in past studies of environmental behaviours (Scott \& Willits 1994; Tarrant \& Cordell 1997; Chen et al. 2013): gender (female $=1$, male $=0$ ), age (categorical with increments of 10 years), education (categorical), household size $(1,2,3,4,5,6$ or more), ethnicity (white $=1$, others $=0)$, income (categorical) and home ownership (own $=1$, other $=$ $0)$. We included these variables in our analysis in order to control for confounding effects and compared our results with past studies on environmental attitudes and behaviour. In our analyses of electricity consumption, we also included three housing structural variables that may affect housing energy use (Abbott \& Meentemeyer 2005; Nelson et al. 2012; Brounen et al. 2013): year built (categorical), thermostat temperature setting $\left(25.6^{\circ} \mathrm{C}\right.$ or above $=1$, other $\left.=0\right)$ and floor area of the house (categorical). We also included a variable in our analyses of vehicle fuel consumption to measure the use of alternative transportation: bus, bike and walk (took a bus or used biking or walking for transportation in the past month $=1$ and 0 otherwise).

\section{Analytical methods}

We calculated Cronbach's alpha on respondents' engagement in purchasing six green products to measure their internal consistency. Due to a high level of internal consistency among measures of purchasing six types of green products (Cronbach's alpha $=0.75)$, we aggregated these measures in a green consumerism scale that could range from 6 to 30 , with a higher score corresponding to higher engagement in green consumerism. We also calculated Cronbach's alpha on responses to $15 \mathrm{NEP}$ statements that indicated a high internal consistency (Cronbach's alpha $=0.79$ ). Despite multi-dimensionality in the NEP, we used the items as a scale (as is typically done). We aggregated item scores in a NEP score ranging from 15 to 75, with a higher score corresponding to more pro-environmental attitude. We used ordinary least squares (OLS) regression models to explore relationships between environmental attitudes (NEP score) and three types of environmental behaviours: green consumerism, summer electricity consumption and vehicle fuel consumption. We tested potential correlations among different types of environmental behaviours using these models. We also controlled for a group of demographic, social and structural characteristics often used in environmental behaviour studies (Scott \& Willits 1994; Mainieri et al. 1997; Tarrant \& Cordell 1997; Brechin 1999; Vaske et al. 2001; Gatersleben et al. 2002; Hunter et al. 2004; Abbott \& Meentemeyer 2005; Abrahamse \& Steg 2009; Jones \& Kammen 2011; Brounen et al. 2013). All statistical analyses were conducted using STATA 11 (STATA Corp., College Station, Texas, USA).

\section{RESULTS}

Respondents of the survey had a mean green consumerism score of 18.70 (Table 1). Their average summer 2012 electricity bill was US\$377.73, and they consumed 1729.88 litres of fuel on average in 2012. The mean NEP score of respondents was 56.24 . The sample was $63 \%$ female, with the mean age of 4.42 corresponding to a range of $41-50$ years old, and the mean education level of 5.23 corresponded to a level between bachelor's degree and graduate degree (Table 1). Most respondents $(83 \%)$ were white, mean household size was 2.54 , and the mean annual household income level was 4.63 corresponding to approximately US\$75,000. Most of the homes were built after 1980, the mean floor area level of the homes was 3.46 corresponding to approximately $180 \mathrm{~m}^{2}$. Approximately $61 \%$ of the respondents owned a home. Only $22 \%$ of the respondents had a thermostat temperature setting above $25.6^{\circ} \mathrm{C}$. Among respondents in the sample, $68 \%$ reported taking a bus or using biking or walking for transportation in the previous month (Table 1).

The green consumerism score was significantly positively correlated with respondents' environmental attitudes (Table 2). One unit increase in NEP score increased the green consumerism score by 0.17 . Several sociodemographic factors were also significantly correlated with the green consumerism scale (Table 2). Being female increased the green consumerism score by 1.53. Educational and income levels were also significantly positively correlated with the green consumerism score.

Unlike green consumerism, neither the summer electricity bill nor the vehicle fuel consumption were correlated with the NEP score (Tables 3 and 4). On average, the summer electricity bill of female respondents was US\$69.79 higher than that of male respondents (Table 3 ). White respondents spent an average of US\$102.02 more on summer electricity than other respondents. One unit increase in household size increased the summer electricity bill by an average of 
Table 1 Summary statistics of environmental behaviours, environmental attitude, and demographic, social and structural characteristics of respondents. NEP = New Ecological Paradigm.

\begin{tabular}{|c|c|c|c|}
\hline Variables & Description & Mean & Standard deviation \\
\hline Green consumerism scale & $\begin{array}{l}\text { Aggregation of engagement in purchasing six } \\
\text { green products }\end{array}$ & 18.70 & 4.72 \\
\hline Summer electricity bill & Sum of 3 months' electricity bill for summer 2012 & 377.73 & 231.57 \\
\hline Vehicle fuel consumption & $\begin{array}{l}\text { Fuel consumption of household's primary vehicle } \\
\text { in } 2012 \text { (litres) }\end{array}$ & 1729.88 & 1136.61 \\
\hline NEP score & Aggregation of responses to $15 \mathrm{NEP}$ statements & 56.24 & 8.63 \\
\hline Gender & Female $=1 ;$ Male $=0$ & 0.63 & 0.48 \\
\hline Age & $\begin{array}{l}\text { Less than } 20 \text { years old }=1 ; 21-30 \text { years old }=2 ; \\
31-40 \text { years old }=3 ; 41-50 \text { years old }=4 ; 51-60 \\
\text { years old }=5 ; 61-70 \text { years old }=6 ; 71-80 \text { years } \\
\text { old }=7 ; \text { Over } 80 \text { years old }=8\end{array}$ & 4.42 & 1.77 \\
\hline Education & $\begin{array}{l}\text { Less than high school }=1 ; \text { high school or } \\
\text { equivalent }=2 ; \text { some college, no degree }=3 ; \\
\text { associates degree }=4 ; \text { bachelor's degree }=5 ; \\
\text { graduate degree or equivalent }=6\end{array}$ & 5.23 & 1.17 \\
\hline Ethnicity & White $=1 ; 0$ otherwise & 0.83 & 0.37 \\
\hline Household size & Number of people in household & 2.54 & 1.30 \\
\hline Income & $\begin{array}{l}\text { Annual household income: }<\$ 25000=1 ; \$ 25 \\
000-34999=2 ; \$ 35000-49999=3 ; \$ 50 \\
000-74999=4 ; \$ 75000-99999=5 ; \$ 100 \\
000-149999=6 ; \$ 150000-249999=7 ; \geq \$ 250 \\
000=8\end{array}$ & 4.63 & 2.24 \\
\hline Year built & $\begin{array}{l}\text { Home built year: before } 1949=1 ; 1950-1979=2 ; \\
\qquad 1980-1999=3 ; 2000-2013=4\end{array}$ & 2.72 & 0.86 \\
\hline Floor area & $\begin{array}{l}\text { Floor area of the house }\left(\mathrm{m}^{2}\right):<93=1 ; 93-139= \\
\quad 2 ; 139-186=3 ; 186-232=4 ; 232-279=5 ; \\
\quad>279=6\end{array}$ & 3.46 & 1.81 \\
\hline Home ownership & Own $=1$, Other $=0$ & 0.61 & 0.49 \\
\hline Thermostat & Above $25.6^{\circ} \mathrm{C}=1$; below $25.6^{\circ} \mathrm{C}=0$ & 0.22 & 0.42 \\
\hline Bus/bike/walk & $\begin{array}{l}\text { Took a bus or used biking or walking for } \\
\text { transportation in the past month }=1 ; 0 \\
\text { otherwise }\end{array}$ & 0.68 & 0.47 \\
\hline
\end{tabular}

Table 2 Ordinary least squares of green consumerism scale on environmental attitudes (NEP) and sociodemographic factors. ${ }^{*} p$ $\leq 0.05 ;{ }^{* *} p \leq 0.01 ;{ }^{* * *} p \leq 0.001 ; \mathrm{n}=185$. NEP $=$ New Ecological Paradigm.

\begin{tabular}{lcc}
\hline \hline $\begin{array}{l}\text { Independent } \\
\text { variables }\end{array}$ & $\begin{array}{l}\text { Coefficients } \\
\text { [standardized } \\
\text { coefficients] }\end{array}$ & $\begin{array}{l}\text { Standard } \\
\text { errors }\end{array}$ \\
\hline NEP score & $0.17^{* * *}[0.31]$ & 0.04 \\
Gender & $1.53^{*}[0.16]$ & 0.68 \\
Age & $0.21[0.08]$ & 0.22 \\
Education & $0.98^{* *}[0.24]$ & 0.32 \\
Ethnicity & $-0.90[-0.07]$ & 0.89 \\
Household size & $-0.13[-0.04]$ & 0.31 \\
Income & $0.43^{*}[0.20]$ & 0.20 \\
Home ownership & $-1.15[-0.12]$ & 0.91 \\
Constant & 1.58 & 3.09 \\
Adjusted $\mathrm{R}^{2}$ & 0.21 & \\
\hline \hline
\end{tabular}

US\$60.65. The summer electricity bill was also significantly affected by structural variables (Table 3 ). One unit increase in respondents' housing floor area increased the summer electricity bill by US $\$ 61.92$ on average. In addition, the summer electricity bill of respondents whose thermostat temperature setting above $25.6^{\circ} \mathrm{C}$ was US $\$ 97.34$ less on average than other respondents. Younger respondents' fuel consumption was significantly greater than their older counterparts (Table 4). Neither the summer electricity bill nor the vehicle fuel consumption were correlated with the green consumerism scale (Table 3 and 4).

\section{DISCUSSION}

Our findings suggest the relationship between proenvironmental attitudes and behaviour may only hold for the less important but more heavily marketed pro-environmental behaviours. Most environmental behaviour studies utilize the theories of reasoned action and planned behaviour (Fishbein \& Ajzen 1975; Ajzen 1991) to suggest pro-environmental attitudes directly or indirectly promote pro-environmental behaviours (Buttel 1987; Kaiser et al. 1999; Dunlap et al. 2000). We found that pro-environmental attitudes were significantly correlated with well marketed but low impact behaviours 
Table 3 Ordinary least squares of summer electricity bill on environmental attitudes (NEP), sociodemographic and structural factors, and green consumerism scale. ${ }^{*} p \leq 0.05 ;{ }^{* * *} p \leq 0.001 ; \mathrm{n}$ $=185 . \mathrm{NEP}=\mathrm{New}$ Ecological Paradigm.

\begin{tabular}{lcr}
\hline $\begin{array}{l}\text { Independent } \\
\text { variables }\end{array}$ & $\begin{array}{l}\text { Coefficients } \\
\text { [standardized } \\
\text { coefficients] }\end{array}$ & $\begin{array}{l}\text { Standard } \\
\text { errors }\end{array}$ \\
\hline NEP score & $-1.97[-0.07]$ & 2.13 \\
Gender & $69.79^{*}[0.15]$ & 35.09 \\
Age & $10.48[0.07]$ & 12.85 \\
Education & $3.84[0.02]$ & 19.97 \\
Ethnicity & $102.02^{*}[0.16]$ & 47.94 \\
Household size & $60.65^{* * *}[0.35]$ & 17.22 \\
Income & $-8.75[-0.08]$ & 12.25 \\
Year built & $12.63[0.04]$ & 21.59 \\
Floor area & $61.92^{* * *}[0.46]$ & 15.66 \\
Home ownership & $-43.41[-0.08]$ & 52.59 \\
Thermostat & $-97.34^{*}[-0.16]$ & 44.21 \\
Green consumerism & $6.34[0.13]$ & 4.02 \\
$\quad$ scale & & \\
Constant & 137.85 & 178.01 \\
Adjusted $\mathrm{R}^{2}$ & 0.46 & \\
\hline \hline
\end{tabular}

identified as green consumerism, but were not correlated with high impact behaviours (Bin \& Dowlatabadi 2005; Jones \& Kammen 2011) driving household electricity or vehicle fuel consumption. These activities are typically not conspicuous and do not promote social status. Because status competition only promotes publicly visible environmental behaviour (Griskevicius et al. 2010), our findings suggest policy should be developed to make environmental behaviours more conspicuous (for example using programmable thermostats) thereby promoting social status (Sexton \& Sexton 2014). Making household energy usage data publicly evaluable, even at the neighborhood level, would achieve both goals (Peterson et al. 2013). Indeed, simply mailing people energy usage of similar households has instigated a $3 \%$ drop in electricity and gas consumption of householders (Allcott \& Mullainathan 2010). Similar impacts may be achieved by promoting information related to household transportation (for example walkability scores) during real-estate transactions.

These efforts to promote meaningful environmental behaviours, however, must compete with massive marketing efforts to capitalize on green premiums for a diverse array of products, also known as greenwashing. A distinction between greenwashing, where dubious claims are made, and green marketing, where the claims are more accurate, can be made, but in practice very few products marketed in either way have meaningful environmental impacts relative to household energy usage and transportation choices (Laufer 2003; Ramus \& Montiel 2005). Although studies have found that green consumerism has little or no effects on reducing the environmental impacts of consumption (Alfredsson 2004; Csutora 2012), most consumers may obtain their knowledge about green products from green marketing that aims at
Table 4 Ordinary least squares of vehicle fuel consumption on environmental attitudes (NEP), sociodemographic and structural factors, and green consumerism scale. ${ }^{*} p \leq 0.05 ;{ }^{* *} p \leq 0.01 ; \mathrm{n}=$ 185. NEP = New Ecological Paradigm.

\begin{tabular}{lcr}
\hline \hline $\begin{array}{l}\text { Independent } \\
\text { variables }\end{array}$ & $\begin{array}{l}\text { Coefficients } \\
\text { [standardized } \\
\text { coefficients] }\end{array}$ & $\begin{array}{l}\text { Standard } \\
\text { errors }\end{array}$ \\
\hline NEP score & $-1.00[-0.01]$ & 11.49 \\
Gender & $50.20[0.02]$ & 194.43 \\
Age & $-187.06^{* *}[-0.30]$ & 65.58 \\
Education & $-82.27[-0.08]$ & 99.26 \\
Ethnicity & $518.61[0.16]$ & 270.55 \\
Household size & $151.93[0.17]$ & 89.57 \\
Income & $89.40[0.17]$ & 58.01 \\
Home ownership & $-48.53[-0.02]$ & 254.68 \\
Bus/bike/walk & $-321.99[-0.14]$ & 204.71 \\
Green consumerism & $-12.38[-0.05]$ & 23.51 \\
$\quad$ scale & & \\
Constant & $2203.31^{*}$ & 917.36 \\
Adjusted $\mathrm{R}^{2}$ & 0.11 & \\
\hline \hline
\end{tabular}

capturing green premiums. This may explain why green consumerism is seen as relatively simple and as having low impacts on people's daily lives (Gatersleben et al. 2002; Pedersen \& Neergaard 2006) relative to reducing household energy consumption despite the relatively simple actions householders can take that can produce $30-40 \%$ reductions in household energy usage without negatively impacting their lifestyle (Dietz et al. 2009; Peterson et al. 2013). The lack of correlation between environmental attitudes and energy consumption in this study may also reflect the NEP measuring general environmental attitudes, which can be different from attitudes toward more specific actions (Mainieri et al. 1997; Gatersleben et al. 2002).

Our findings regarding relationships between income, education level and gender support the general disconnect found between environmental attitudes and significant environmental behaviours. Specifically, our finding that females participated in green consumerism more than males corroborates indications that females have more proenvironmental attitudes and are more likely to participate in pro-environmental behaviour than males (Dietz et al. 1998; Vaske et al. 2001). However, we found that in Chapel Hill the gender difference was reversed when moving from green consumerism to more meaningful behaviours, and that households of female respondents actually used more energy than those of male respondents. This observation, however, should be the subject of future research since intuitive explanations for higher household energy usage are not obvious, and multiple interpretations are possible. For instance, households where women responded being more likely to have women who spend time at home during work hours and thus use more energy.

Income and education provided more evidence for the disconnect between green consumerism and more meaningful 
environmental behaviours. Both variables have long been associated with pro-environmental attitudes and behaviours (Van Liere \& Dunlap 1980; Scott \& Willits 1994; Jones \& Kammen 2011), and both were positively related to green consumerism but not related to household energy usage or vehicle fuel consumption. Recent research on income suggests more pro-environmental attitudes and behaviour among economically disadvantaged people (Brechin \& Kempton 1994; Dunlap \& Mertig 1995; Brechin 1999; Dunlap \& York 2008; Chen et al. 2011), particularly when they are disproportionately exposed to environmental harm (Chen et al. 2013). Respondents in our study site had higher educational levels than the nation's average (Social Explorer 2010), which often leads to more pro-environmental attitudes (Buttel 1987; Scott \& Willits 1994; Dunlap et al. 2000), and higher NEP scores than those typically reported in other case studies (Peterson et al. 2008; Pienaar et al. 2015; Steel et al. 2015). Given this context, we should have detected a relationship between significant environmental behaviours and environmental attitudes even if a relatively high threshold in environmental attitudes is required to elicit significant environmental behaviour. These results suggest that improving pro-environment attitudes through education may not be effective in reducing human behaviours that have high impacts on the environment.

We also found age negatively correlated with vehicle fuel consumption, which was intuitive given many older people do not need to drive for work purposes or to provide transportation for children living at home (Barr et al. 2005). Electricity consumption was positively correlated with household size and housing floor area, and was negatively correlated with thermostat temperature setting, which is consistent with past studies (Poortinga et al. 2004; Nelson et al. 2012). White respondents reported higher electricity consumption than other ethnic groups, probably due to the inequities in housing for minorities and the differences in lifestyles and environmental values among different ethnic groups (Johnson et al. 2004; Nelson et al. 2012).

Our results suggest that social and structural constraints are more important than attitudinal and individual level demographic factors in determining home electricity consumption. Conservation efforts that aim to reduce humans' environmental impacts, especially greenhouse gas emissions, would do better to focus on either addressing social and structural constraints or competing effectively with the green consumerism marketing professionals. The limited role of structural variables on vehicle fuel use may reflect recall bias associated with distance driven among respondents. Because summer electricity usage was based on utility bills, relationships in the model predicting household electricity usage are probably more rigorous. Future research using direct observation of vehicle distance driven or fuel consumption would reduce any recall bias problems, but the observation itself may alter behaviour unless participants are unaware of study intentions (Barr et al. 2005).

\section{ACKNOWLEDGEMENTS}

We gratefully acknowledge the financial support from the US National Science Foundation (grant number DEB-1313756) and The University of North Carolina at Chapel Hill. We thank Ms. Audrey Jo for assistance in data collection, and the editor in chief, the associate editor and two anonymous reviewers for their constructive criticisms on an earlier draft of this paper.

\section{References}

Abbott, J. A. \& Meentemeyer, V. (2005) Research note - vegetation effects on suburban air conditioning. Urban Geography 26(6): 558564.

Abrahamse, W. \& Steg, L. (2009) How do socio-demographic and psychological factors relate to households' direct and indirect energy use and savings? Fournal of Economic Psychology 30(5): 711-720.

Ajzen, I. (1991) The theory of planned behavior. Organizational Behavior and Human Decision Processes 50(2): 179-211.

Alfredsson, E. C. (2004) “Green" consumption - no solution for climate change. Energy 29(4): 513-524.

Allcott, H. \& Mullainathan, S. (2010) Behavior and energy policy. Science 327(5970): 1204.

Attari, S. Z., DeKay, M. L., Davidson, C. I. \& de Bruin, W. B. (2010) Public perceptions of energy consumption and savings. Proceedings of the National Academy of Sciences of the United States of America 107(37): 16054-16059.

Barr, S., Gilg, A. W. \& Ford, N. (2005) The household energy gap: examining the divide between habitual- and purchase-related conservation behaviours. Energy Policy 33(11): 1425-1444.

Becker, L. J., Seligman, C., Fazio, R. H. \& Darley, J. M. (1981) Relating attitudes to residential energy use. Environment and Behavior 13(5): 590-609.

Bin, S. \& Dowlatabadi, H. (2005) Consumer lifestyle approach to US energy use and the related $\mathrm{CO}_{2}$ emissions. Energy Policy 33(2): 197-208.

Brechin, S. R. \& Kempton, W. (1994) Global environmentalism a challenge to the postmaterialism thesis. Social Science Quarterly 75(2): 245-269.

Brechin, S. R. (1999) Objective problems, subjective values, and global environmentalism: evaluating the postmaterialist argument and challenging a new explanation. Social Science Quarterly 80(4): 793-809.

Brounen, D., Kok, N. \& Quigley, J. M. (2013) Energy literacy, awareness, and conservation behavior of residential households. Energy Economics 38: 42-50.

Buttel, F. H. (1987) New directions in environmental sociology. Annual Reviem of Sociology 13: 465-488.

Chen, X. D., Peterson, M. N., Hull, V., Lu, C. T., Hong, D. Y. \& Liu, J. G. (2013) How perceived exposure to environmental harm influences environmental behavior in urban China. Ambio 42(1): $52-60$.

Chen, X. D., Peterson, M. N., Hull, V., Lu, C. T., Lee, G. D., Hong, D. Y. \& Liu, J. G. (2011) Effects of attitudinal and sociodemographic factors on pro-environmental behaviour in urban China. Environmental Conservation 38(1): 45-52.

Csutora, M. (2012) One more awareness gap? The behaviour-impact gap problem. Fournal of Consumer Policy 35(1): 145-163. 
Dietz, T., Gardner, G. T., Gilligan, J., Stern, P. C. \& Vandenbergh, M. P. (2009) Household actions can provide a behavioral wedge to rapidly reduce US carbon emissions. Proceedings of the National Academy of Sciences of the United States of America 106(44): 1845218456.

Dietz, T., Stern, P. C. \& Guagnano, G. A. (1998) Social structural and social psychological bases of environmental concern. Environment and Behavior 30(4): 450-471.

Dunlap, R. E. \& Mertig, A. G. (1995) Global concern for the environment: is affluence a prerequisite? Fournal of Social Issues 51(4): 121-137.

Dunlap, R. E. \& Michelson, W., eds. (2002) Handbook of Environmental Sociology, Westport, CT, USA: Greenwood.

Dunlap, R. E. \& Van Liere, K. D. (1978) The "New Environmental Paradigm": a proposed measuring instrument and preliminary results. Fournal of Environmental Education 9(4): 10-19.

Dunlap, R. E. \& York, R. (2008) The globalization of environmental concern and the limits of the postmaterialist values explanation: evidence from four multinational surveys. Sociological Quarterly 49(3): 529-563.

Dunlap, R. E., Van Liere, K. D., Mertig, A. G. \& Jones, R. E. (2000) Measuring endorsement of the new ecological paradigm: a revised NEP scale. Fournal of Social Issues 56(3): 425-442.

Fishbein, M. \& Ajzen, I. (1975) Belief, Attitude, Intention and Behavior: An Introduction to Theory and Research, Reading, MA, USA: Addison-Wesley.

Gardner, G. T. \& Stern, P. C. (2008) The short list - the most effective actions US households can take to curb climate change. Environment 50(5): 12-24.

Gatersleben, B., Steg, L. \& Vlek, C. (2002) Measurement and determinants of environmentally significant consumer behavior. Environment and Behavior 34(3): 335-362.

Gilg, A., Barr, S. \& Ford, N. (2005) Green consumption or sustainable lifestyles? Identifying the sustainable consumer. Futures 37(6): 481-504.

Griskevicius, V., Tybur, J. M. \& Van den Bergh, B. (2010) Going green to be seen: status, reputation, and conspicuous conservation. Fournal of Personality and Social Psychology 98(3): 392.

Hunter, L. M., Hatch, A. \& Johnson, A. (2004) Cross-national gender variation in environmental behaviors. Social Science Quarterly 85(3): 677-694.

IPCC (2014) Climate change 2014: Mitigation of Climate Change. Working Group III contribution to the IPCC Fifth Assessment Report. Cambridge, United Kingdom: Cambridge University Press.

Johnson, C. Y., Bowker, J. M. \& Cordell, H. K. (2004) Ethnic variation in environmental belief and behavior: an examination of the new ecological paradigm in a social psychological context. Environment and Behavior 36(2): 157-186.

Jones, C. M. \& Kammen, D. M. (2011) Quantifying carbon footprint reduction opportunities for US households and communities. Environmental Science E Technology 45(9): 4088-4095.

Kaiser, F. G., Wölfing, S. \& Fuhrer, U. (1999) Environmental attitude and ecological behaviour. Fournal of Environmental Psychology 19(1): 1-19.

Laufer, W.S. (2003) Social accountability and corporate greenwashing. Fournal of Business Ethics 43(3): 253-261.

Mainieri, T., Barnett, E. G., Valdero, T. R., Unipan, J. B. \& Oskamp, S. (1997) Green buying: the influence of environmental concern on consumer behavior. Fournal of Social Psychology 137(2): 189-204.
Moisander, J. (2007) Motivational complexity of green consumerism. International fournal of Consumer Studies 31(4): 404-409.

Nelson, C., McHale, M. R. \& Peterson, M. N. (2012) Influences of landscape and lifestyle on home energy consumption. Urban Ecosystems 15(4): 773-793.

Pedersen, E. R. \& Neergaard, P. (2006) Caveat emptor - let the buyer beware! Environmental labelling and the limitations of 'green'consumerism. Business Strategy and the Environment 15(1): $15-29$.

Peterson, M. N., Chen, X. D. \& Liu, J. G. (2008) Household location choices: implications for biodiversity conservation. Conservation Biology 22(4): 912-921.

Peterson, M. N., Peterson, T. \& Liu, J. (2013) The Housing Bomb: Why Our Addiction to Houses Is Destroying the Environment and Threatening Our Society, Baltimore, MD, USA: JHU Press.

Pienaar, E. F., Lew, D. K. \& Wallmo, K. (2015) The importance of survey content: testing for the context dependency of the New Ecological Paradigm Scale. Social Science Research 51: 338-349.

Poortinga, W., Steg, L. \& Vlek, C. (2004) Values, environmental concern, and environmental behavior - a study into household energy use. Environment and Behavior 36(1): 70-93.

Ramus, C. A. \& Montiel, I. (2005) When are corporate environmental policies a form of greenwashing? Business ES Society 44(4): 377 414.

Roberts, J. A. \& Bacon, D. R. (1997) Exploring the subtle relationships between environmental concern and ecologically conscious consumer behavior. Fournal of Business Research 40(1): 79-89.

Roberts, J. A. (1996) Green consumers in the 1990s: profile and implications for advertising. Fournal of Business Research 36(3): 217-231.

Schultz, P. W. \& Oskamp, S. (1996) Effort as a moderator of the attitude-behavior relationship: general environmental concern and recycling. Social Psychology Quarterly 59(4): 375-383.

Schultz, P. W. \& Zelezny, L. C. (1998) Values and proenvironmental behavior - a five-country survey. Fournal of Cross-Cultural Psychology 29(4): 540-558.

Scott, D. \& Willits, F. K. (1994) Environmental attitudes and behavior - a Pennsylvania survey. Environment and Behavior 26(2): 239-260.

Sexton, S. E. \& Sexton, A. L. (2014) Conspicuous conservation: the Prius halo and willingness to pay for environmental bona fides. Fournal of Environmental Economics and Management 67(3): 303317.

Social Explorer (2010) Tables (SE), Census 2010. [www document]. URL http://www.socialexplorer.com/

Sparks, P. \& Shepherd, R. (1992) Self-identity and the theory of planned behavior - assessing the role of identification with green consumerism. Social Psychology Quarterly 55(4): 388-399.

Steel, B. S., Pierce, J. C., Warner, R. L. \& Lovrich, N. P. (2015) Environmental value considerations in public attitudes about alternative energy development in Oregon and Washington. Environmental Management 55(3): 634-645.

Stern, P. C., Dietz, T. \& Guagnano, G. A. (1995) The new ecological paradigm in social-psychological context. Environment and Behavior 27(6): 723-743.

Stern, P. C., Dietz, T. \& Kalof, L. (1993) Value orientations, gender, and environmental concern. Environment and Behavior 25(5): 322-348. 
Tarrant, M. A. \& Cordell, H. K. (1997) The effect of respondent characteristics on general attitude-behavior correspondence. Environment and Behavior 29(5): 618-637.

Tindall, D. B., Davies, S. \& Mauboules, C. (2003) Activism and conservation behavior in an environmental movement: the contradictory effects of gender. Society $\mathbb{E}$ Natural Resources 16(10): 909-932.

Van Liere, K. D. \& Dunlap, R. E. (1980) The social bases of environmental concern: a review of hypotheses, explanations and empirical evidence. Public Opinion Quarterly 44(2): 181-197.
Vaske, J. J., Donnelly, M. P., Williams, D. R. \& Jonker, S. (2001) Demographic influences on environmental value orientations and normative beliefs about national forest management. Society $\mathcal{E}$ Natural Resources 14(9): 761-776.

Vining, J. \& Ebreo, A. (1992) Predicting recycling behavior from global and specific environmental attitudes and changes in recycling opportunities. Fournal of Applied Social Psychology 22(20): 1580-1607.

Widegren, O. (1998) The new environmental paradigm and personal norms. Environment and Behavior 30(1): 75-100. 